\title{
The Russian Specificity of Developing Process of the Disbalance in Structure of the Individual Human Capital
}

\author{
Tatyana Vladimirovna Kasaeva \\ Svetlana Viktorovna Anufrienko
}

Pyatigorsk State Linguistic University, Russia, 357500, Stavropolsky krai, Pyatigorsk, Kalinin str., 9

Rud Natalya Yurevna

North Caucasus Federal University, Russia, 357500, Stavropolsky krai, Pyatigorsk, Matveeva str., 35b

Kiseleva Natalya Nikolaevna

Notrh-Caucasus Institute-branch of Russian Presidential Academy of National Economy and Public Administration, 357500 Stavropolsky krai, Pyatigorsk, Fevralsky str., 54

\section{Doi:10.5901/mjss.2015.v6n5s2p405}

\section{Abstract}

\begin{abstract}
At present in the international scientific community one speaks more persistently about necessity of social investments developing which are associated with accumulation of the human capital. Reproduction of the human capital becomes a part of "present - future" problematic with key problems of public necessity and balance of investments into the physical, social and individual human capita. Transformational imperatives, coming out in concrete historical conditions, every time impose certain specificity on social and economic relations which comes out not only in country dynamics of processes but also in the alternative and unstable character of transformation, its nonlinearity, and also in specific "transitive" forms of public relations. Especially actual for the Russian economy at the moment is the analysis of adequacy extent of these transformations to problems of development of the Russian society. In this article the authors concentrated their attention on studying of the imperative of reproduction of the individual human capital and revealing the reasons of the disbalance in the structure of the human capital in the Russian economy. Authors come to the conclusion that the origin of the disbalance between structural elements of the human capital in Russia is connected with a phase of use of manpower. The carried out research showed that the Russian economic system defined with the "bureaucratic capitalism" definition, demonstrates inability to effective reproduction of the human capital in its unity of individual, corporate and national levels owing to objective directivity of processes control mechanisms to the solution of formal but not substantial problems.
\end{abstract}

Keywords: human capital, labour force, disproportion of economic development, Russia

\section{Introduction}

The extent of development of the human capital depends not so much on the rate of the invested financial assets and labour, technological and material level of society development, but on features of economic relations and those institutions which are related with reproduction of the concrete capital form. In this connection there are two positions of considering this category.

In particular, from the technological viewpoint the human capital is considered not as whole set (as in the traditional definition) of abilities, skills and knowledge of workers united in the competence, but as the whole set of concrete technologies with the human being as their bearer.

From the institutional viewpoint the human capital is considered as the whole set of specific economic relations, social and labour first of all.

The present extent of the social production development obviously shows that in its structure the human capital represents one of the most significant economic categories. Such state of things causes significant interest of Russian scientists to the given phenomenon.

The main problem of their scientific researches is to find ways of improvement of the human capital quality in Russia that is extremely actual today for two principal reasons: 
1) intensification and duration of the system crisis in Russia shows difficulty of its management in any ways, except orientation of the state policy to effective social and economic development;

2) reaching the majority of developed countries the stage of postindustrial development that results in dependence of the Russian economy in the system of the international division of labour.

The main purposes of this study are:

- to reveal an imperative of the individual human capital reproduction connected with dialectics of economic interests;

- to define reasons of disbalance in the structure of the human capital in the Russian economy.

\section{Literature Review}

The theory of the human capital has long history and develops in parallel with civilizational concepts of 20th and the beginning of $21_{\text {th }}$ centuries.

At the origins of the human capital theory in its current form were Becker (1975), Bowen (1978), Schultz (1960), Thurow (1970) who studied the human capital as of the whole set of all productive qualities of the worker.

In spite of the fact that in the western economic thought there is no unified approach to research of the human capital the distinctive feature of the further development out of theory by Ben-Porath (1967), Blaug (1970), Blair (1996), Machlup (1984), Martin (2000), etc. is the "investment" treatment of the human capital. At the microlevel the key problem of the human capital research consisted in an assessment of efficiency of investments into its various components, at the macrolevel - in an assessment of influence of investments into human abilities on the economic growth. Political, economic and applied problems connected with labour relations, reproduction of the labour force, labour motivation were a subject of scientific researches of Adjibolosoo (1998), Burke and Cooper (2005), Florida (2014), Gimpelson and Kapeliushnikov (2014), Kasaeva (2014), Lokshin et al. (2012), Mathur (1999), Walker (2000) and others.

\section{Research Methods}

The job methodology is determined by the political and economic approach to research of the social and economic relations connected with reproduction of the individual human capital, realized on the basis of the dialectic method in unity with general scientific and special research methods, first of all, with the method of scientific abstraction, analysis and synthesis, genetic, system and historical methods, economic and statistical information processing methods, with the method of the structural and functional analysis that allowed to realize unity of theoretical and empirical analysis of the research subject field.

Owing to the objective complexity of the scientific problem itself, the problem solution requires searching for new theoretical and methodological approaches.

These approaches, leaning on the fundamental methodological bases of the political economy - the dialectic method of cognition, the concrete and historical approach, general classes should be attached to the modern historical context in which: first, information becomes the main object of economic relations; secondly, economic relations itself are becoming international under the influence of global conversion; thirdly, there is a tendency to the work individualization as consequence of the contradiction between progressing specialization of labour, on the one hand, and its socialization on the other, and, fourthly, there is a transformation of the production relations system, connected with public necessity of formation of the competitive model of Russia's participation in International Division of Labour.

\section{Results and Discussion}

The growing significance of quality improvement of the labour power for the Russian economy is connected with several circumstances. First, there is a threat both of degradation and subsequent exhaustion of the human capital of the country, that first of all can be explained by the low social living standard, and, accordingly, by population decline due to degradation of public health services and education quality. The process of the qualitative man power reproduction together with growth of the human capital quality can be realized only on condition of complete satisfaction of needs of the population in those means of subsistence which can supply accumulation of abilities, skills and knowledge of the human being.

Secondly, the present problem of the human capital quality improvement is also connected with the processes of formation and development of market relations at the labour market. It is expressed in contradictions, first of all caused by discrepancy of the available professional and qualification structure of human potential in organizations to structure of 
demand for work, caused by new labour types which require absolutely other qualifying skills of the human being. The main problem is that the majority of such labour types includes specialists with the lower level of professional qualification.

Thirdly, an insignificant part of the human capital in the structure of the national wealth of the country. The national wealth in Russia is formed mainly due to use of the natural capital which is ineffectively used in connection with the low quality of the human capital. Low quality of the human capital also leads to curtailing of the most science intensive branches of industry and scientific researches. Just in such areas in which requirements for the qualitative human capital constantly increase.

Almost in all programs, strategies and other official documents containing priorities of the Russian (and its regions) economy development the human capital is present. However it is insufficiently thoroughly examined and explained. Consideration of necessity of its quality raise includes only investments into public health system and education. Really, at first sight, dysfunction of human capital reproduction system in Russia exists in the phase of its formation, evidence of which they search in the state of things in the sphere of education and public health services. However the determinative value in destructive processes, in our opinion, has the demand for the human capital from corporations and the state. As Gimpelson and Kapeliushnikov (2013) noted, the Russian economy now can be characterized for sure as "the barrel with disproportions". Existing deformalization of our country economy causes doubts concerning sufficiency of demand from economy on the workers with higher education, despite the fact, that significant demand for higher education is present from the population. Such state of things causes considerable disproportions in the structure of the human capital.

In Russia there are no structural and technological conditions for effective absorption of the human capital by the national economy. A serious problem for an economic complex of Russia is growing structural disproportionality. Unlike countries of the postindustrial development where technologies of the fifth wave of innovation prevail and the sixth wave of begins economy of Russia is characterized by technological multistructurality and backwardness of the technological structure. In the middle of nineties the share of the fifth wave in economy of Russia made only $2 \%$, and of the first and the second (relict) ways - $9 \%$. The same structure was in economy of the USA in the end of forties and the beginnings of fiftieth.

It is necessary to note, that in developed countries already by the end of ninetieth of the past century more than $70 \%$ of all financial resources were invested in the human capital while only about $30 \%$ in the physical capital. In particular, in advanced countries the prevailing volume of investments in the human capital belongs to the state. This feature should be considered as one of the main state functions in the area of stimulation and economy regulation. However in Russia, and also in some other countries with the struggling economy characterized by backwardness in the innovative development and development of the industry in whole, the concept of the economic category "the human capital" as the intensive factor of the modern economy and society development is of not wide use.

Significant structural disproportions which were formed in economy of Russia during the directive management of the public economy which largely hindered current development of the country, undoubtedly, occur. Thus they are not restricted only by disbalance between supply and demand on the human capital. Such disproportions cause low competitiveness of the domestic goods in comparison with their foreign analogues as well. Such problems have sources in objective regularity of reproduction of the institutional and technological structure of the directive economy. Such state of things causes presence of the technological multistructurality and increasing lack in technology which is connected with it. In the market economy change processes of technological waves are associated with processes of resources redistribution outside the reproduction frames of the former technological wave into expansion of the replacing frame, and they also associated with perfection of the industrial potential on the updated technological basis. In command-andcontrol economy change and formation of more perfect technological waves is carried out with conservation of previous waves elements which was provided by corresponding industrial and bureaucratic systems. In connection with these circumstances there is a special situation connected with formation of reproduced technological multistructurality of the social production which is able to entail growth of technological disproportions which, in their turn, lead to slowing down of innovative technological shifts and economic growth rate (Glazyev, 1993).

Now the Russian economy goes on lagging behind the majority of the developed countries which made a significant breakthrough in development of the fifth technological wave and carried out on this basis modernization of their economies for the last ten years. In particular, one should note, that the significant gap between the USA and Russia in cumulative expenses for education shows lagging of Russian economy in the extent of utilization and development of the human capital from demands of the fifth technological wave. So, in education this gap comes up today 5,7 times, and 12 times in public health services at all. In fact, the state cannot create worthy conditions for the normal process of the human potential reproduction, that, in turn, makes favorable economic development in the foreseeable future impossible. This process is also promoted and continued by "brain drain", expressed in migration of ten thousand competent 
specialists and researchers of scientists abroad in a year.

Current trends of depreciation of the human capital in Russia and its degradation put in question the role of the key source of advancing of scientific and technical progress, and, hence, social and economic development - intelligence together with creative activity of people. Such trends are direct opposite to the mass process of raise of educational level of the population, the role of intellectual labour, creation of the social partnership relations directly connected with existing technological transformations. Rooting of similar negative trends can cause further essential decrease in competitiveness and loss of independence of development of the Russian economy, not capable to provide in the future the level of labour productivity on the basis of education, innovations and life quality matching to the new technological wave. Technological transformations taking place in the Russian economy, are negatively characterized that entailed the rapid degradation of its industrial structure for the past some decades. The most significant regress rooted in the advanced branches and was expressed in the form of the state economy setback of the state in 10-25 years. The majority of the branches connected with production of final products and completing the circle of the fifth technological wave, does not function effectively. Reduction of such productions considerably exceeds decline in production of other branches that led to their practically complete replacement from home market with foreign competitors. Rapid deformation of productions within the fifth technological wave entailed destructive tendencies of the technological basis of the stable economic growth that makes very difficult for the Russian economy to get out from the prolonged deep depression.

The current prolonged depression of the Russian economy is an obvious pathology which is characterized by chaotic decomposition of the economic system in connection with its degradation.

Disintegration of the integral reproduction contours into independent structures which partially adapted in external reproduction contours, can entail only negative aftereffects in a long-term prospect. Loss of the reproduction integrity together with destruction of the key components of the scientific and industrial potential and swift curtailment of scales of scientific developments and researches, and also prevailing of the external reproduction contours in the structure of economy can give rise only loss of economic independence, but also can influence destruction of internal reserves of the stable economic growth in connection with transformation of the national economy into the extremely unstable and vulnerable system depending on conditions of the global market.

One more negative tendency in disproportions of the Russian economy and in use of the aggregated human capital is that, despite cheap labour monopolization of economy deprives Russian corporations of stimulus to the innovative activity. Monopolism by its nature denies the "employee-centered" approach, and it's an immanent property of the "bureaucracy and corporate capitalism", including its state superstructure. In the market economy there is a quite tangible possibility of monopolization of concrete spheres of the national economy, including possibility of establishing barriers to higher education. In such conditions the income of the human capital driver can be characterized as rental (personal rent).

There are two types of the personal rent of human capital drivers:

1) The status personal rent which can be gained in the course of economic relations which are characterized by a situation when the restricted number of people has a free access to higher education, and who, as a rule, belong to elite social groups. In such situation the driver of the human capital has the right to the substantial personal rent. The similar type of the personal rent on the human capital is generally characteristic for developing countries. It is connected with the fact that in the majority of these countries there are still class, estate and property barriers which prevent the majority of the population from getting worthy education.

2) The innovative personal rent which is typical for developed countries. The basic source of an additional income is not the social status, but a rather high return from use of the human capital in the most progressive and high technology branches. The object of monopolization in this case is those competitive advantages which countries have due to implementation of prevailing model of globalization. Manufacturing and realizing products in the world market at exclusively heavy prices, these countries buy raw materials in old industrial branches at exclusively low prices. As a result they have the innovative rent part of which is appropriated by qualified specialists. The majority of the countries with less developed economy has no such advantages.

Concerning the Russian economy there are no reasons to speak about innovative personal rents of human capital drivers. Our country has not managed to pass to the innovative model of the economic growth yet that stipulates absence of the innovative personal rent. Job opportunities for a significant part of workers with higher education are restricted enough, and the salary is still low. Realization of the innovative model of the economic development in Russia becomes the only possible condition of using its currently unclaimed human capital.

For more complete realization of the human capital potential in the national economy and increasing efficiency of its use the significant role is played by the national strategy of use and development of the productive forces which leader is the human capital. Such strategy should provide (within its structure) for attention to such spheres as public health 
services, education, and also should have the macroeconomic model in which innovative factors of production are in priority.

Such national strategy is capable to provide transition from basing on available competitive advantages to basing on the acquired competitive advantages (Trunin, 2009).

The following problem which generating disproportionality of development of the human capital is caused by the fact that expected by the Center of migratory researches reduction of the able-bodied population of Russia by 2020 in 1819 million people is explained first of all by reduction of the aggregate capital of the nation's health that is the logic continuation of position \# 161 of Russia in 2010 in a world life span rating. As possibility for a man to take part in the labour activity depends on dynamics of national health parameters, the population's health should be considered as the main condition of functioning of the human capital. Deterioration of health quality of individuals leads to the significant economic damage. So, deterioration of population's health of the Russian Federation involved in economy is proportionate to annual losses of 6,5\% of gross national product (Prokhorov and Tikunov, 2005).

Specialists of the budgetary sphere face the problem (with simultaneous financial restrictions) of distribution of financial resources on realization of different public health services programs which usually include limited groups of diseases.

\section{Conclusion}

Priority problems of the Russian public administration system in this case include following:

1) fixing strategic targets and priorities of the social and economic development;

2) realization of the effective professional training, use of potential of scientists, specialists, and also results of their activity;

3) arrangement of favourable social, material and technical conditions for their most effective labour;

Achievements connected with accumulation and perfection of the human capital abroad are directly connected with penetration into essence of laws of cultural and social and economic development, and also with modernization of available management technologies of the social and scientific progress. At present, states which have created substantial volumes of the qualitative human capital, have stable advantages. According to this fact, it's not difficult to come to the conclusion, that exactly understanding by managers, power structures and scientists of the potential strategic worth of the human capital observed as the primary factor of development of the state and the company, provides with cardinally new possibilities for creating substantial advantages for the national economy, and also for developing social and cultural strategies of safety and resistant to social and economic development of the state and establishing conditions for the favourable and reliable future of the state.

The situation which emerged in the system of the human capital reproduction in the modern Russia, proves that economic laws are always realized with activity of people with their driving stimulus of economic interests which in certain public conditions are determined, first of all, by property relations of the, and which are capable to transform mechanisms of economic laws implementation. It is necessary to remind, that economic interest shows the objective necessity of satisfying some needs of the individual, and it also shows the activity stipulated by it which results lead to satisfaction of needs.

As there is a differentiation connected with separation of the property into common and private, it is a basis for common and private economic interests. Analyzing economic interests, mediating relations concerning the human capital, such separation is quite appropriate because property in the human capital is presented both in private, and in common forms. The first category includes at that directly human capital of every man, the consolidated human capital functioning within private company. The second category is the human capital of the family, the aggregate human capital of the social group, separate region or the nation in whole. On the basis of it, it is necessary to study communities of economic interests at all these levels (family, social group, region, state), keeping in mind at that specificity of private interests based on the corporate and private corporate property. Economic interest of any certain contractor in the market of the human capital is based on his quite certain needs, and also on some economic relations which are generally expressed in property relations. Such characteristic gives a possibility to estimate the abovementioned market as a specific system with the basis of needs of certain individuals and their communities, and also their functioning within concrete types and forms of property relations which actively develop together with economic relations stipulating not only directly economic interests themselves, but their contradictory unity as well. The analysis of economic interests of counterparts in the market of the human capital opens possibility of formation of the general representation about relations which develop in the given market.

Despite various mentioned groups of economic interests depending on stated categories, there is a united interest 
which is connected with considered problems of market relations. This interest is connected with growth of volumes and quality of the aggregated human capital and the extent of its conformity to nation's interests. This feature is of great importance taking into account that fact, that achievement of economic and social stability directly correlates with raise of productivity of use of the aggregated human capital and its quality as well.

The key moment in this problem is that modernization of public health services and education systems together with increase in the aggregated human capital of the nation reproduce each other on the basis of multiplier effect.

Thus, the imperative of the human capital reproduction, at level of economic relations, is taxonomy of economic interests to requirements of the principal economic law of social wealth growth.

\section{References}

Adjibolosoo, S.B-S. (1998). International perspectives on the human factor in economic development. Westport: Praeger Publishers.

Becker, G.S. (1975). Human capital: a theoretical and empirical analysis, with special reference to education. New York: Columbia University Press for NBER.

Ben-Porath, Y. (1967). The production of human capital and the life cycle of earning. The Journal of Political Economy, 75(4), 352-365.

Blair, M.M. ( 1996). Wealth creation and wealth sharing: a colloquium on corporate governance and investments in human capital. Washington: The Brookings Institution.

Blaug, M. (1970). An introduction to the economics of education. London: Allen Lane.

Bowen, H.R. (1978). Investment in learning. San Francisco: Jossey-Bass.

Burke, R.J. and Cooper, C.L. (2005). Reinventing human resources management: challenges and new directions. London: Routledge.

Florida, R. (2014). The creative class and economic development. Economic Development Quarterly, 28, 196-205.

Gimpelson, V.E., and Kapeliushnikov, R. (2014). Polarization or Upgrading? Evolution of Employment in Transitionary Russia. Working papers by IZA. Series "IZA Discussion Paper". Discussion Paper 8688. http://www.hse.ru/pubs/lib/data/access/ram/ticket/34/ 14283209954591c359d373c7863924f3a0501c31ed/dp8688.pdf

Gimpelson, V.E., and Kapeliushnikov, R. (2013). Labor Market Adjustment: Is Russia Different? Working papers by IZA. Series "IZA Discussion Paper". Discussion Paper 5588. http://ttp.iza.org/dp5588.pdf

Glazyev, S.Y. (1993). The theory of long-term technological and economic development. Moscow: VlaDar.

Kasaeva, T.V., Kiseleva, N.N., Rud, N.Y. (2014). Human Capital Contribution into Innovation Progress: World Experience. Life Science Journal, 11(11), 626-629.

Lokshin, M., Gimpelson, V., and Oshchepkov A. (2012). Explaining the Dynamics in Perceptions of Job Insecurity in Russia. Working papers by Institute for the Study of Labor. Discussion Paper 6422. http://www.hse.ru/pubs/lib/data/access/ram/ticket/47/14 283282771dc947569cfecbc2a90a44eddeedc445/dp6422.pdf

Machlup, F. (1984). The economics of information and human capital. Princeton: Princeton University Press.

Martin, C. (2000). Stuck in neutral: business and the politics of human capital investment policy. Princeton: Princeton University Press.

Mathur, V.K. (1999). Human capital-based strategy for regional economic development. Economic Development Quarterly, 13(3), 203216.

Prokhorov, B.B. and Tikunov, V.S. (2005). Medical and demographic classification of regions of Russia. Forecasting problems, 4, 69-70.

Schultz, T. (1960). Capital formation by education. The Journal of Political Economy, 68, 571.

Thurow, L. (1970). Investment in human capital. Belmont: Wadsworth Publishing Company.

Trunin, S.N. (2009). Labour economics. Moscow: Economica.

Walker, D.M. (2000). Strategic human capital management: the critical link. The Public Manager, 29(1), 5. 